\title{
EPIDEMIOLOGY OF POLYTRAUMA IN A TERTIARY CARE CENTRE
}

\author{
Nipun Kalsotra1, Vidhu Mahajan², Gopika Kalsotra ${ }^{3}$, Siddhartha Sharma ${ }^{4}$, Prince Raina ${ }^{5}$, Anil Gupta ${ }^{6}$ \\ ${ }^{1}$ Senior Resident, Department of Orthopaedics, Government Medical College, Jammu. \\ ${ }^{2}$ Demonstrator, Department of Pathology, Government Medical College, Jammu. \\ ${ }^{3}$ Lecturer, Department of ENT, Government Medical College, Jammu. \\ 4 Senior Resident, Department of Orthopaedics, Government Medical College, Jammu. \\ 5Junior Resident, Department of Orthopaedics, Government Medical College, Jammu. \\ ${ }_{6}$ Professor and HOD, Department of Orthopaedics, Government Medical College, Jammu.
}

\section{ABSTRACT}

Polytrauma is a major cause of morbidity and mortality in both developed and developing countries. The term "Polytrauma" is mainly used to describe blunt trauma patients whose injuries involve multiple body regions or cavities, compromise patient's physiology and potentially cause dysfunction of uninjured organs. This study about epidemiology of fractures in polytrauma patients was carried out in emergency of Orthopaedics Department, Government Medical College, Jammu. The study was done for a duration of one year. Data was collected related to age, sex, mode of injury, date, time of injury and admission, pattern of fractures, associated injuries as per in the standard protocol proforma. Then various mechanisms of trauma were correlated to the type of injuries, to define pattern of injuries encountered in various accidents in polytrauma victims and then analysis of data was done.

\section{KEYWORDS}

Polytrauma, Fracture, Injury.

HOW TO CITE THIS ARTICLE: Kalsotra N, Mahajan V, Kalsotra G, et al. Epidemiology of polytrauma in a tertiary care centre. J. Evolution Med. Dent. Sci. 2016;5(47):3021-3025, DOI: 10.14260/jemds/2016/703

\section{INTRODUCTION}

With the advancement in field of Science and Technology, morbidity and mortality due to infectious and other diseases has decreased, but deaths due to trauma have increased tremendously. In most countries, trauma is the common cause of death after cardiovascular diseases and neoplasia, most common among young people in the age group of 18-44 years worldwide. Polytrauma is a major cause of morbidity and mortality in both developed and developing countries. ${ }^{[1]}$ The term "Polytrauma" is mainly used to describe blunt trauma patients whose injuries involve multiple body regions or cavities, compromise patient's physiology and potentially cause dysfunction of uninjured organs. ${ }^{[2]}$ Polytrauma is one of the main causes of death in the world. Since young people are frequently involved, trauma is the leading cause of death under the age of 40.[3]

Polytrauma is defined as the clinical state following injury to body leading to profound physio-metabolic changes involving multiple systems. The criteria for polytrauma include any one of the following combinations of injuries:

- Two major systems involved along one major lung injury.

- One major system involved along with two major skeletal injury.

- Unstable fracture pelvis with associated visceral injuries.

- $\quad$ One major system injury with one open grade III skeletal injury.

The basic fact and final goal of trauma care can be summarized in one very simple issue.

Financial or Other, Competing Interest: None.

Submission 10-03-2016, Peer Review 20-05-2016,

Acceptance 26-05-2016, Published 13-06-2016.

Corresponding Author:

Dr. Nipun Kalsotra,

House No.-10, Sector-A, Subash Nagar,

Jammu-180005,

Jammu \& Kashmir.

E-mail: nipunkalsotra@yahoo.com

DOI: $10.14260 /$ jemds/2016/703
"The injured patient must obtain the best treatment possible. The heaviest toll of traumatic deaths occurs within the first hour following trauma, often defined as "The golden hour of trauma." [4] A rough estimate indicates that $15 \%$ of all hospitals and clinical beds are occupied by victims, thus making polytrauma as one of the single leading cause of hospital admission.[5]

For describing patients with multiple injuries and evaluating emergency care, various scoring system have evolved over time like-Injury Severity Score (ISS), Glasgow Coma Scale (GCS), Revised Trauma Score.

\section{AIMS AND OBJECTIVES}

1. To study age, sex, mode of injury, time of injury and duration, after which patient came to our hospital.

2. To study about fractures in polytrauma patients in reference to age, sex, bone involvement, associated visceral injuries, etc.

3. To study factors, which influence the accidents and find out preventive aspects for them.

4. To evaluate need of a fully equipped specialized trauma care centre/hospital in this region.

\section{MATERIAL AND METHODS}

This study about epidemiology of fractures in polytrauma patients was carried out in Emergency of Orthopaedics Department, Government Medical College, Jammu, which is a provincial referral hospital for Jammu-the winter capital of state of Jammu and Kashmir. The study was done for duration of one year.

\section{The Criteria Laid Down for the Present Study were as} Follows:

1. Patients who had injury severity score greater/equal to 16.

2. Patients below 10 years of age were not included. 
3. Polytrauma patients who had sustained injury within 48 to 72 hours were included in the study. Old referred cases were not included.

Those polytrauma patients who had bony injuries along with other associated injuries and fulfilled the above criteria were included in the study. Each patient was assessed regarding his general condition and the injuries. Proper emergency management of the patient consisting of intravenous fluids, medications, blood transfusion, splintages, etc. was done. A detailed history from each victim and his attendants was obtained. The patients were meticulously examined using the primary and secondary survey for all the evidences of trauma and the general condition. All findings were charted for each decedent and recorded as in standard protocol proforma.

Radiographic scanning was done in all cases and other necessary investigations were done as per the need of the patient. The injuries were graded according to abbreviated injury scale. From this information, the injury severity score was calculated.

Following data was collected: age, sex, mode of injury, date, time of injury and admission, pattern of fractures, associated injuries as per in the standard protocol proforma. Then various mechanisms of trauma were correlated to the type of injuries, to define pattern of injuries encountered in various accidents in polytrauma victims and then analysis of data was done.

\section{OBSERVATIONS}

\begin{tabular}{|c|c|c|}
\hline Age in Years & No. of Patients & Percentage \\
\hline $10-20$ & 43 & 16.7 \\
\hline $21-30$ & 80 & 31.0 \\
\hline $31-40$ & 69 & 26.7 \\
\hline $41-50$ & 38 & 14.7 \\
\hline $51-60$ & 17 & 6.6 \\
\hline$>60$ & 11 & 4.3 \\
\hline Total & $\mathbf{2 5 8}$ & $\mathbf{1 0 0}$ \\
\hline \multicolumn{3}{|c|}{ Table 1: Age Distribution } \\
\hline
\end{tabular}

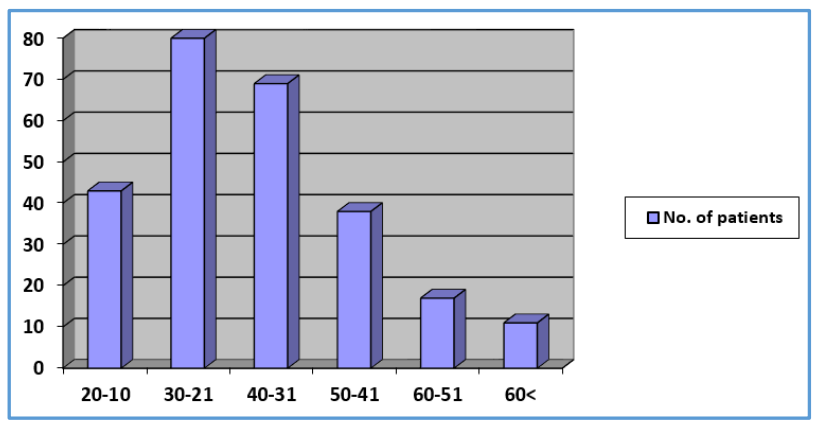

The age of patients in this study varied from 11 to 66 years. It was observed that majority of the polytrauma victims were in the age group of $21-40$ years (57.7 percent). The mean age of the patients was 31.5 years.

\section{INJURY SEVERITY SCORE}

\begin{tabular}{|c|c|c|c|c|c|c|c|}
\hline $\begin{array}{c}\text { Age } \\
\text { Group }\end{array}$ & $\begin{array}{c}\mathbf{1 6 -} \\
\mathbf{2 5}\end{array}$ & $\begin{array}{c}\mathbf{2 6 -} \\
\mathbf{3 5}\end{array}$ & $\begin{array}{c}\mathbf{3 6 -} \\
\mathbf{4 5}\end{array}$ & $\begin{array}{c}\mathbf{4 6 -} \\
\mathbf{5 5}\end{array}$ & $\begin{array}{c}\mathbf{5 6}- \\
\mathbf{6 5}\end{array}$ & $\begin{array}{c}\mathbf{6 6 -} \\
\mathbf{7 5}\end{array}$ & Total \\
\hline $10-20$ & 23 & 15 & 3 & 2 & & & 43 \\
\hline $21-30$ & 43 & 25 & 6 & 5 & 1 & & 80 \\
\hline
\end{tabular}

\begin{tabular}{|c|c|c|c|c|c|c|c|}
\hline $31-40$ & 46 & 17 & 4 & 2 & & & 69 \\
\hline $41-50$ & 21 & 12 & 3 & 2 & & & 38 \\
\hline $51-60$ & 11 & 2 & 2 & & & & 17 \\
\hline$>60$ & 11 & & & & & & 11 \\
\hline Total & $\mathbf{1 5 5}$ & $\mathbf{7 1}$ & $\mathbf{1 8}$ & $\mathbf{1 1}$ & $\mathbf{1}$ & $\mathbf{2 5 8}$ \\
\hline \multicolumn{7}{|c|}{ Table 2: Relationship Between Injury Severity } \\
\hline
\end{tabular}

The severity of various injuries occurring among polytrauma victims was most, in the age group of 21-40 years. Highest injury score ranging from 55-65 was observed in 1 patient within the age group of 21-30 years. The mean ISS score value observed was 26.7 .

\begin{tabular}{|c|c|c|}
\hline Sex & No. of Patients & Percentage \\
\hline Male & 204 & 79.1 \\
\hline Female & 54 & 20.9 \\
\hline Total & 258 & 100 \\
\hline \multicolumn{2}{|c|}{ Table 3: Sex Distribution } \\
\hline
\end{tabular}

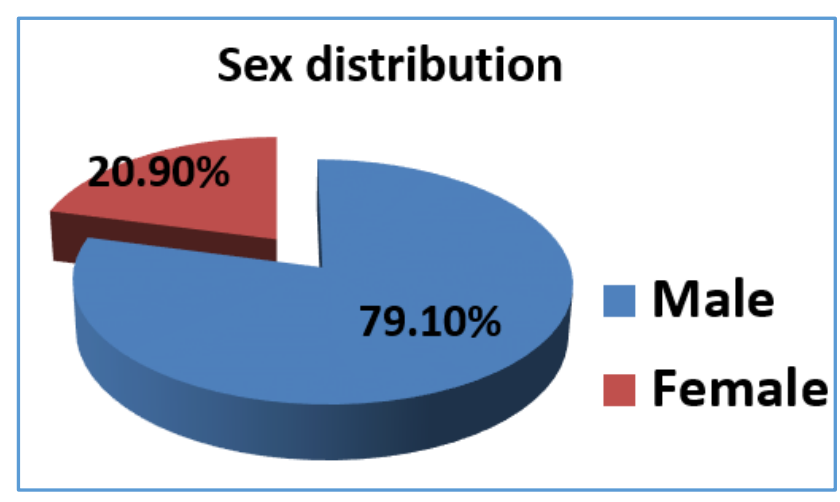

It was observed that males were predominant over females among polytrauma victims. There were 204 males (79.1 percent) and 54 females (20.9 percent). Male-to-female ratio was 3.8:1.

\begin{tabular}{|c|c|c|}
\hline $\begin{array}{c}\text { Time before } \\
\text { Hospitalization } \\
\text { (In Hours) }\end{array}$ & $\begin{array}{c}\text { No. of } \\
\text { Patients }\end{array}$ & Percentage \\
\hline $0-4$ & 177 & 68.6 \\
\hline $5-8$ & 27 & 10.4 \\
\hline $9-12$ & 14 & 5.4 \\
\hline $13-16$ & 11 & 4.3 \\
\hline $17-20$ & 9 & 3.5 \\
\hline $21-24$ & 8 & 3.1 \\
\hline $25-28$ & 5 & 1.9 \\
\hline $29-32$ & 3 & 1.2 \\
\hline $33-36$ & 2 & 0.8 \\
\hline$>36$ & 2 & 0.8 \\
\hline Total & 258 & 100 \\
\hline
\end{tabular}




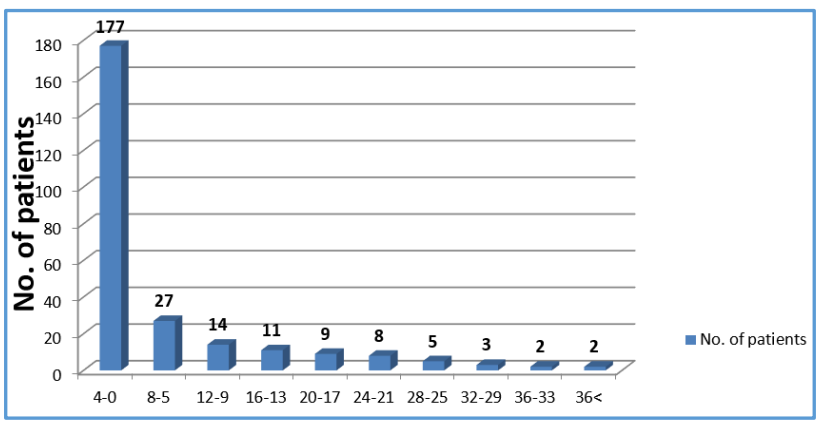

In our study, we observed that 68.6 percent (177) of cases reached to the hospital in less than 4 hours after the injury. Average time before hospitalization was 5.1 hours. Those patients who reported late were usually from the far flung areas.

\begin{tabular}{|c|c|c|c|c|}
\hline $\begin{array}{l}\text { Sl. } \\
\text { No. }\end{array}$ & \multicolumn{2}{|c|}{$\begin{array}{l}\text { Mode of } \\
\text { Injury }\end{array}$} & $\begin{array}{l}\text { No. of } \\
\text { Cases }\end{array}$ & Percentage \\
\hline 1 & \multicolumn{2}{|c|}{ Road traffic accidents } & 197 & 76.4 \\
\hline 2 & \multicolumn{2}{|c|}{ Fall from height } & 27 & 10.5 \\
\hline \multirow{3}{*}{3} & \multirow{3}{*}{ Assault } & Sharp & 11 & 4.3 \\
\hline & & Blunt & 8 & 3.1 \\
\hline & & Missile & 9 & 3.5 \\
\hline & \multicolumn{2}{|c|}{ Assault Total } & 28 & 10.9 \\
\hline \multirow[t]{2}{*}{4} & \multicolumn{2}{|c|}{ Miscellaneous } & 6 & 2.2 \\
\hline & \multicolumn{2}{|c|}{ Total } & 258 & 100 \\
\hline \multicolumn{5}{|c|}{ Table 5: Mode of Injury } \\
\hline
\end{tabular}

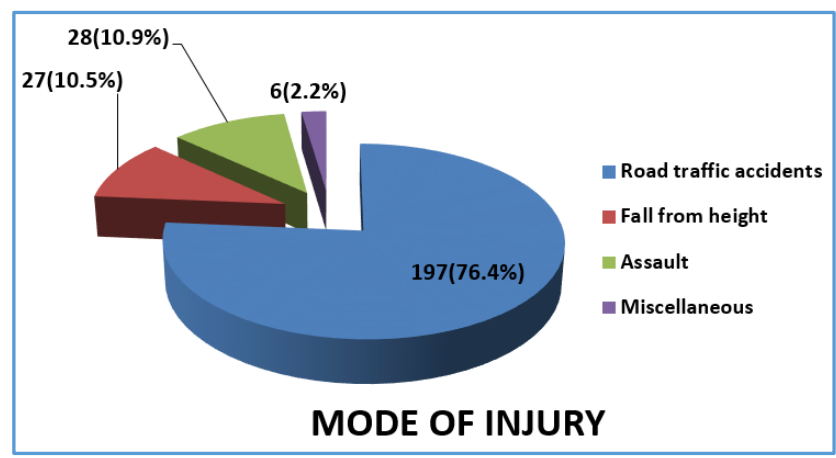

The commonest mode of injury seen among polytrauma victims was road traffic accidents. It accounted for 76.4 percent of cases followed by assault, which accounted for 10.9 percent of cases; 4.3 percent of assault cases were injured by sharp edged objects; 3.1 percent of cases by blunt objects and another 3.5 percent of cases due to missile injury. Fall from height like unprotected balcony, from tree, from hill, etc. resulted in injuries among 10.5 percent of polytrauma victims; 2.2 percent of polytrauma victims suffered injuries due to miscellaneous causes.

\begin{tabular}{|c|c|c|c|}
\hline $\begin{array}{c}\text { Sl. } \\
\text { No. }\end{array}$ & $\begin{array}{c}\text { Type of Vehicle } \\
\text { Involved }\end{array}$ & $\begin{array}{c}\text { No. of } \\
\text { Cases }\end{array}$ & Percentage \\
\hline 1. & Jeep/Car & 30 & 15.2 \\
\hline 2. & Two wheeler & 53 & 26.9 \\
\hline 3. & Bus/Truck & 56 & 28.4 \\
\hline 4. & Tractor & 5 & 2.5 \\
\hline 5. & Bicycle & 3 & 1.5 \\
\hline 6. & Pedestrian & 50 & 25.4 \\
\hline \multicolumn{3}{|c|}{ Table 6: Distribution of Different Class of Road } \\
Traffic Accidents \\
\hline \multicolumn{4}{|c|}{} \\
\hline
\end{tabular}

Among polytrauma victims who suffered injuries due to road traffic accidents, bus or truck was the most common vehicle involved in 28.4 percent (56) patients. It was followed by two wheelers in 26.9 percent (56) cases. Pedestrians formed the third group in 25.4 percent $(50)$ cases followed by car/jeep in 15.2 percent ( 30 ) cases. In Indian conditions where tractor is used for multipurpose, it was involved in 2.5 percent (5) cases.

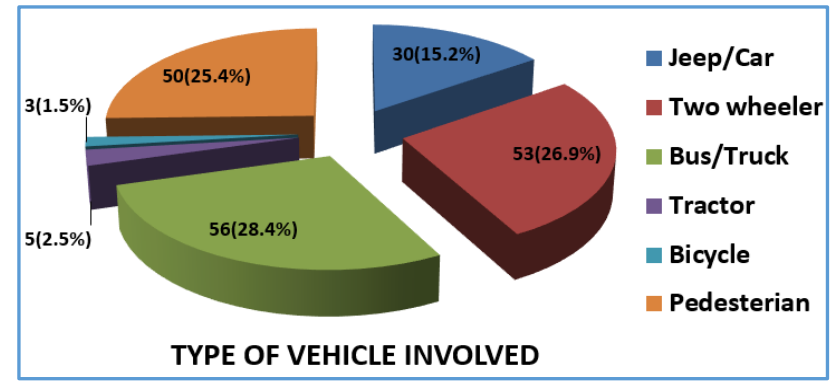

\begin{tabular}{|c|c|c|c|}
\hline $\begin{array}{l}\text { Sl. } \\
\text { No. }\end{array}$ & Age in Years & No. of Patients & Percentage \\
\hline 1. & $\begin{array}{c}6.00 \mathrm{am} \text { to } 10.00 \\
\mathrm{am}\end{array}$ & 13 & 6.6 \\
\hline 2. & $\begin{array}{c}10.00 \text { am to } 2.00 \\
\mathrm{pm}\end{array}$ & 41 & 20.8 \\
\hline 3. & $\begin{array}{c}2.00 \mathrm{pm} \text { to } 6.00 \\
\mathrm{pm}\end{array}$ & 68 & 34.5 \\
\hline 4. & $\begin{array}{c}6.00 \mathrm{pm} \text { to } 10.00 \\
\mathrm{pm}\end{array}$ & 39 & 19.8 \\
\hline \multirow[t]{2}{*}{5.} & $\begin{array}{c}10.00 \mathrm{pm} \text { to } 6.00 \\
\mathrm{am}\end{array}$ & 36 & 18.3 \\
\hline & Total & 197 & 100 \\
\hline & $\begin{array}{r}\text { ble 7: Involvem } \\
\text { Differ }\end{array}$ & $\begin{array}{l}\text { te of Traffic } A \\
\text { irs of the Day }\end{array}$ & ents at \\
\hline
\end{tabular}

It was observed that maximum brunt of road traffic accidents was seen during afternoon hours between 2.00 to $6.00 \mathrm{pm}$. Out of 197 cases, 34.5 percent (68) occurred during these hours of day light. Between 10.00 am to $2.00 \mathrm{pm}$ we found 20.8 percent (41) cases, while between 6.00 and 10.00 am only 6.6 percent (13) cases occurred. Between $6.00 \mathrm{pm}$ to $10.00 \mathrm{pm} 19.8$ percent cases (39) occurred. During night hours between $10.00 \mathrm{pm}$ and 6.00 am only 18.3 percent (36) cases occurred.

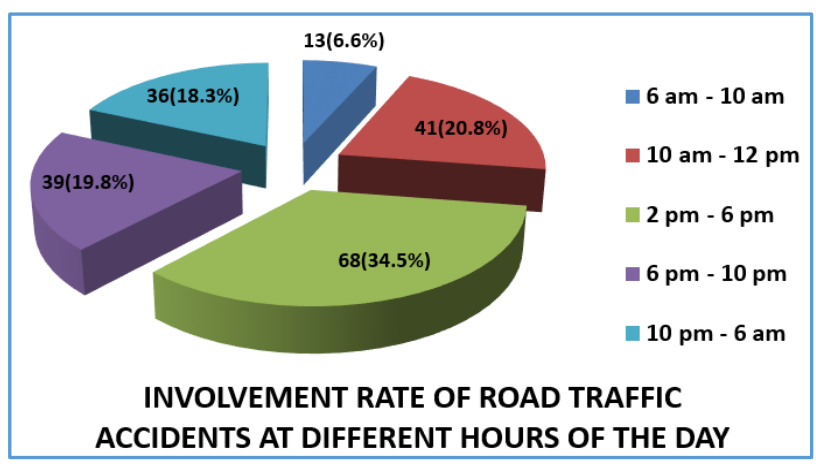

\begin{tabular}{|c|c|c|c|}
\hline $\begin{array}{l}\text { Sl. } \\
\text { No. }\end{array}$ & $\begin{array}{l}\text { Basic Cause of } \\
\text { Accident }\end{array}$ & $\begin{array}{l}\text { No. of } \\
\text { Cases }\end{array}$ & Percentage \\
\hline 1. & $\begin{array}{l}\text { Due to driving while } \\
\text { intoxicated with alcohol }\end{array}$ & 19 & 9.6 \\
\hline 2. & Due to other reasons & 178 & 90.4 \\
\hline & Total & 197 & 100 \\
\hline
\end{tabular}


Out of polytrauma cases who suffered injuries because of traffic accidents, 33 were drivers, 114 were non-drivers and 50 were pedestrians. Out of 33 drivers, 19 were intoxicated with alcohol.

\section{Fracture Pattern}

\begin{tabular}{|c|c|c|c|c|}
\hline & Humerus & $\begin{array}{c}\text { Radius } \\
\text { and Ulna }\end{array}$ & Hand & Clavicle \\
\hline $\begin{array}{c}\text { Fractures } \\
\text { (Total No.) }\end{array}$ & 70 & 104 & 57 & 27 \\
\hline $\begin{array}{c}\text { Fractures } \\
\text { (\% of all) }\end{array}$ & 8.5 & 12.6 & 6.9 & 3.3 \\
\hline $\begin{array}{c}\text { Fractures } \\
\text { Closed (\%) }\end{array}$ & 77.1 & 71.2 & 71.9 & 100 \\
\hline $\begin{array}{c}\text { Fractures } \\
\text { Open (\%) }\end{array}$ & 22.9 & 28.8 & 28.1 & 0 \\
\hline \multicolumn{7}{|c|}{ Table 9: Incidence of Fractures in Upper Extremity } \\
\hline
\end{tabular}

There were 825 fractures in our series of 258 polytrauma patients. Upper limb fractures were 31.3 percent (258) of total series.

\begin{tabular}{|c|c|c|c|c|c|}
\hline & Femur & $\begin{array}{c}\text { Tibia } \\
\text { and } \\
\text { Fibula }\end{array}$ & Patella & Ankle & $\begin{array}{c}\text { Foot } \\
\text { Bones }\end{array}$ \\
\hline $\begin{array}{c}\text { Fractures } \\
\text { (Total No.) }\end{array}$ & 151 & 187 & 33 & 90 & 106 \\
\hline $\begin{array}{c}\text { Fractures } \\
\text { (\% of all) }\end{array}$ & 18.3 & 26.7 & 4 & 10.9 & 12.8 \\
\hline $\begin{array}{c}\text { Fractures } \\
\text { Closed (\%) }\end{array}$ & 71.5 & 59.9 & 78.8 & 76.7 & 75.5 \\
\hline $\begin{array}{c}\text { Fractures } \\
\text { Open (\%) }\end{array}$ & 28.5 & 40.1 & 21.2 & 23.3 & 24.5 \\
\hline
\end{tabular}

\section{Table 10: Incidence of Fractures in Lower Extremity}

The lower limb bones were more frequently involved than upper limb bones and axial skeleton. Lower limb fractures were 68.7 percent (567) of total series.

\begin{tabular}{|c|c|c|c|c|}
\hline & Humerus & $\begin{array}{c}\text { Radius } \\
\text { and } \\
\text { Ulna }\end{array}$ & $\begin{array}{c}\text { Hand } \\
\text { Bones }\end{array}$ & Clavicle \\
\hline $\begin{array}{c}\text { Simple } \\
(76 \%)\end{array}$ & 54 & 74 & 41 & 27 \\
\hline $\begin{array}{c}\text { Compound } \\
(24 \%)\end{array}$ & 16 & 30 & 16 & 0 \\
\hline Table 11: Fracture of Upper Limb Bones as per Type \\
\hline
\end{tabular}

In upper limb fractures 76 percent (196) were simple and 24 percent (62) were compound.

\begin{tabular}{|c|c|c|c|c|c|}
\hline & $\begin{array}{c}\text { Femu } \\
\mathbf{r}\end{array}$ & $\begin{array}{c}\text { Tibia } \\
\text { and } \\
\text { Fibul } \\
\mathbf{a}\end{array}$ & $\begin{array}{c}\text { Patell } \\
\mathbf{a}\end{array}$ & $\begin{array}{c}\text { Ankl } \\
\mathbf{e}\end{array}$ & $\begin{array}{c}\text { Foot } \\
\text { Bone } \\
\mathbf{s}\end{array}$ \\
\hline $\begin{array}{c}\text { Simple } \\
(69.7)\end{array}$ & 108 & 112 & 26 & 69 & 80 \\
\hline $\begin{array}{c}\text { Compoun } \\
\text { d (30.3) }\end{array}$ & 43 & 75 & 7 & 21 & 26 \\
\hline
\end{tabular}

Table 12: Fracture of Lower Limb Bones as per Type

In lower limb fractures, 69.7 percent (395) were simple and 30.3 percent (172) were compound.

\begin{tabular}{|c|c|c|}
\hline & Spine & Pelvis \\
\hline Simple & 22 & 27 \\
\hline Compound & 0 & 3 \\
\hline \multicolumn{2}{|c|}{ Table 13: Fracture of Spine and Pelvis as per Type } \\
\hline
\end{tabular}

Fractures of spine and pelvis were 2.7 percent (22) and 3.6 percent (30) respectively. In fractures of spine, no compound fracture was seen. In case of pelvic fractures 90 percent (27) were simple and 10 percent (3) were compound.

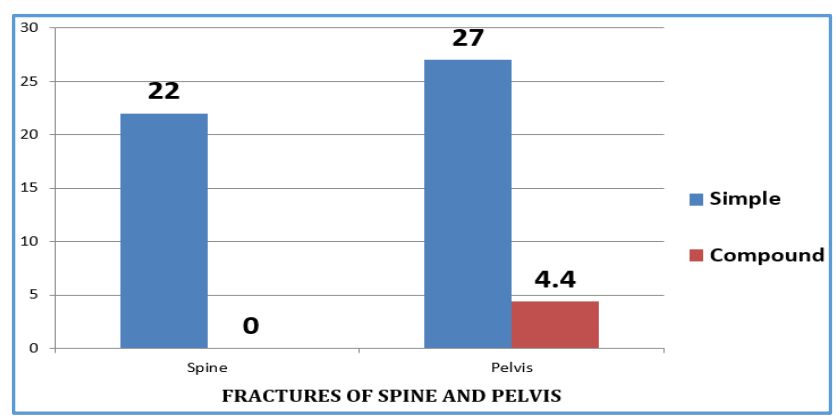

\begin{tabular}{|c|c|c|c|c|}
\hline $\begin{array}{c}\text { Associated } \\
\text { Complications }\end{array}$ & Humerus & $\begin{array}{c}\text { Radius } \\
\text { and } \\
\text { Ulna }\end{array}$ & $\begin{array}{c}\text { Hand } \\
\text { Bones }\end{array}$ & Clavicle \\
\hline Nerve injury & 24 & 18 & 5 & 0 \\
\hline Vascular injury & 8 & 13 & 6 & 0 \\
\hline $\begin{array}{c}\text { Compartment } \\
\text { syndrome }\end{array}$ & 2 & 19 & 11 & 0 \\
\hline Table 14: Associated Complications with Upper Limb \\
Bones Fractures \\
\hline
\end{tabular}

In upper limb, humerus fractures were most commonly associated with nerve injuries. Both vascular injury and compartment syndrome were most commonly associated with fractures of radius and ulna.

\begin{tabular}{|c|c|c|c|c|}
\hline $\begin{array}{c}\text { Associated } \\
\text { Complications }\end{array}$ & Femur & $\begin{array}{c}\text { Tibia } \\
\text { and } \\
\text { Fibula }\end{array}$ & Ankle & $\begin{array}{c}\text { Foot } \\
\text { Bones }\end{array}$ \\
\hline Nerve injury & 5 & 26 & 5 & 8 \\
\hline Vascular injury & 11 & 34 & 6 & 8 \\
\hline $\begin{array}{c}\text { Compartment } \\
\text { syndrome }\end{array}$ & 0 & 37 & 3 & 11 \\
\hline \multicolumn{5}{|c|}{} \\
Table 15: Associated Complications with \\
Lower Limb Bones Fractures \\
\hline
\end{tabular}

In lower limb, both neurovascular injury and compartment syndrome were most commonly associated with fractures of tibia and fibula.

\begin{tabular}{|c|c|c|}
\hline $\begin{array}{c}\text { Type of Associated } \\
\text { Injuries }\end{array}$ & $\begin{array}{c}\text { No. of } \\
\text { Patients }\end{array}$ & Percentage \\
\hline Head injury & 128 & 49.6 \\
\hline Chest injury & 81 & 31.4 \\
\hline Abdominal injury & 89 & 34.5 \\
\hline Facial injury & 25 & 9.7 \\
\hline Table 16: Associated Injuries with Fractures \\
in Polytrauma Patients \\
\hline
\end{tabular}

Head injuries were the commonest associated injuries and were present in 49.6 percent patients.

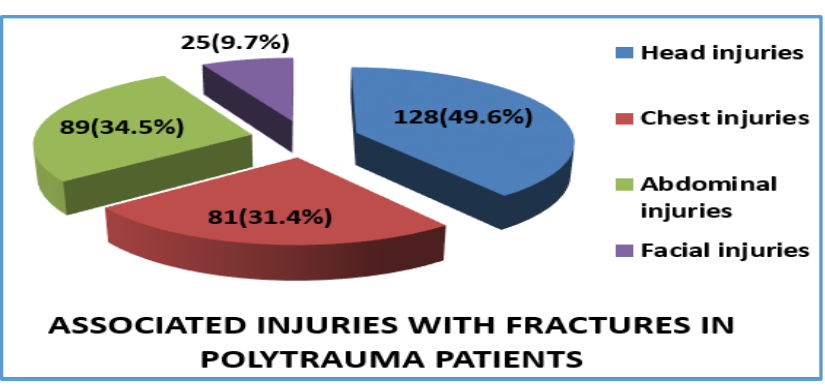




\begin{tabular}{|c|c|c|}
\hline Day of the Week & No. of Patients & Percentage \\
\hline Monday & 42 & 16.3 \\
\hline Tuesday & 32 & 12.4 \\
\hline Wednesday & 35 & 13.6 \\
\hline Thu & 34 & 13.2 \\
\hline Fri & 33 & 12.8 \\
\hline Sat & 38 & 14.7 \\
\hline Sun & 44 & 17.1 \\
\hline \multicolumn{3}{|c|}{ Table 17: Association of Polytrauma Patients } \\
\hline
\end{tabular}

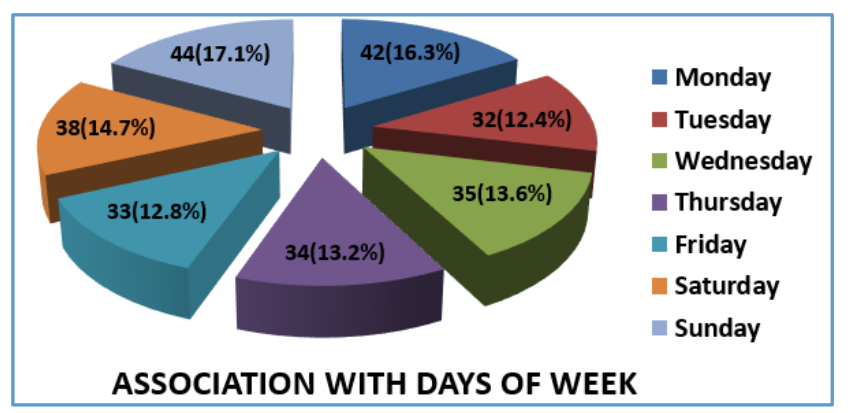

\section{Summary and Conclusion}

This prospective study about epidemiology of fractures in polytrauma patients was conducted for a duration of one year; 258 patients who attended the Emergency of Orthopaedic Department, Government Medical College, Jammu, were included in the study. Observations recorded were subjected to critical analysis. The available literature on the subject was critically reviewed. On the basis of the present study following conclusions may be drawn:

- Majority of the patients were within the age group of 2140 years.

- The severity of various injuries occurring among polytrauma victims was most in the age group of $21-40$ years.

- Majority of the patients reached hospital in less than 4 hours.

- $\quad$ The commonest mode of injury seen was RTA followed by assault and fall from height. Most common vehicle seen involved in RTA was bus/truck followed by two wheeler and maximum RTA were seen between 2.00 to $6.00 \mathrm{pm}$.

- The lower extremity fractures were most frequent among polytrauma victims followed by upper limb fractures. The commonest fractures in order of frequency were those of tibia and fibula, femur, foot bones, ankle, radius and ulna, hand bones, patella and clavicle.

- Compound fractures were more common in lower limb than upper limb. In lower limbs, maximum compound fractures were seen in tibia and fibula and in upper limbs in radius and ulna.

- In upper limb, maximum nerve injuries associated fractures were seen with humerus, maximum vascular injuries with fractures of radius and ulna and maximum compartment syndrome with fractures of radius and ulna.
- In lower limb maximum nerve and vascular injuries and compartment syndrome associated fractures were seen with fracture of tibia and fibula.

- Overall, maximum neurovascular injuries and compartment syndromes were seen with fractures of tibia and fibula.

- Head injury was the commonest associated injury seen fractures.

- If health care services are truly committed for reducing preventable deaths or morbidity, then designation of trauma care and implementation of trauma system is necessary. To avoid any delay and to have a best initial management of polytrauma, patient triage is important. The triage is sorting out of patients, based on the need of treatment and available resources to provide for the treatment.[6]

- There is clearly a need for road safety education and it should be directed towards road users, who are frequently involved and injured in RTAs (e.g. Students). An integrated programme of road safety education is suggested.

a. Pre-school children may be introduced to the elementary concepts of road safety through stories involving the animal world.

b. Primary school children may be given practice guidance on the use of sidewalks and road crossing techniques.

c. For middle school students - road signs and bicycle riding.

d. High school students can be taught about reaction time, braking distance, defensive driving and hazards of alcoholic drinks.

\section{REFERENCES}

1. Matar ZS. The clinical profile of polytrauma and management of abdominal trauma in a general hospital in the central region of the Kingdom of Saudi Arabia. The Internet J Surg 2008;14:11.

2. Butcher N, Balogh ZJ. The definition of polytrauma: the need for international consensus. Injury 2009;40(supplement 4):S12-S22.

3. World Health Organization. The global burden of disease: 2004 update. Geneva, Switzerland: World Health Organization; 2008.

http://www.who.int/healthinfo/global_burden_disease/ en/

4. Kunreuther H. Risk analysis and risk management in an uncertain world. Risk Anal 2002;22(4):655-64.

5. Verghes M. Pre hospital care-introduction to injury control and safety promotion. Paper presented at Delhi, Activity Week of BJD-India 2000.

6. Hassan A, Tesfayohannes B. Initial assessment of the polytrauma patient. Surgery 2009;27(7):275-9. 